\title{
ROAD TRANSPORT IN TOURISM: IMPLEMENTING SUCCESSFULLY AIR TRANSPORT PRACTICES
}

\author{
Emmanouil Christofakis \\ Department of Business Administration, University of the Aegean, Chios, Greece
}

Theodoros Stavrinoudis

Department of Business Administration, University of the Aegean, Chios, Greece

Spyridon Kapitsinas

Laboratory for Tourism Research and Studies, University of the Aegean, Chios, Greece

Andreas Papatheodorou

Department of Business Administration, University of the Aegean, Chios, Greece

Dimitrios Pappas

Department of Business Administration, University of the Aegean, Chios, Greece

Irini Vlassi

Department of Business Administration, University of the Aegean, Chios, Greece

Evangelia Proiou

Laboratory for Tourism Research and Studies, University of the Aegean, Chios, Greece

\begin{abstract}
Transportation has always been closely connected to the development of a region. Technological advancements as well as the increase of the available income has set the fundamentals for more effective ways of transportation. At the same time, tourism flourishes and more people travel around the world. To accommodate this additional demand, airlines introduced several strategies; among others, the Low Cost Carrier (LCC) business model has played a disruptive role. At the same time, road transport operators started to implement several strategies, some of which are inspired from the airline sector. Road transport operations, mainly undertaken by coaches, introduced several strategies to address the evolving demand. This paper presents a wide overview of the Greek road transport sector and its related legal framework. The review aims to identify and discuss the best practices, introduced by the airlines, and fruitfully apply them in the context of the road transport sector.
\end{abstract}

\section{KEYWORDS}

Air Transport, Road Transport, Tourism, Best Practices 


\section{INTRODUCTION}

Transport and in particular the availability of means and the organization of transport networks, the adequacy of infrastructure, as well as the quality of services provided, play a primary role in the spatial distribution, not only of productive activities, but of overall development. It is a common finding that this role is timeless, as it goes through all the historical periods of the economic evolution.

Following the evolution of the location patterns of productive activities and the spatial distribution of settlements, we can observe their close dependence on the development of modes of transport. More specifically, until the mid of $19^{\text {th }}$ century, before the great inventions and the technological change in transportation, the location pattern of productive activities was characterized by a spatial dispersion. The size and the structure of the settlement network in Central Europe during the thirteenth century is the most obvious example. Most of the settlements had a population of less than 30,000 inhabitants and localized in a range of 6 to 20 kilometers (Benevolo, 1980). Gradually, after 1850, an increase of the mobility in population and economic activities has been observed. The steam navigation (1807) and the railway (1829) at first, as well as the car and the airplane later, formed new conditions in spatial mobility through the rapid transportation of goods, employees, customers, and population in general. Moreover, electricity gave the ability for the location and concentration of economic activities far away from the places where traditional sources of energy were produced, while the invention of telegraph, allowed new developments in the telecommunication sector, serving the contact with distant markets and the decision making from distance (Christofakis, 2014). In general, the gradual evolution of transport technology inevitably leads to a rapid increase in the mobility of people and goods and to a time-space convergence, in the sense that a reduction in travel time is transferred from one area to another and consequently enhances the importance of spatial distance or time distance (Bithas and Nijkamp 1997, Lamprianidis, 2001). Indicatively, it is observed that technological developments in the transport sector have allowed the European citizens to increase the annual number of traveled kilometers by about $3 \%$, since the beginning of the $19^{\text {th }}$ century.

Moreover, factors such as the rapid growth of the service sector and the rise in travel requirements of professionals associated with them, the increase in disposable income, resulting in a more massive market for cars and motorcycles and in combination with this an increase in time for leisure, travel, and vacation, also contribute to enhancing the population mobility. It is estimated that in the next 10 years, until 2030, passenger air traffic will be increasing by an annual rate of $3-6 \%$ and at the same time motorized transportation in cities is expected to be doubled between 2015 and 2050 (metaforespress.gr, 2017).

These developments have a direct impact on travel for leisure and tourism in general, which shows a significant increase over time. In the second half of the $20^{\text {th }}$ century the number of tourist arrivals worldwide increased from 25 million in 1952 to 531 million in 1995 to 680 million in 2000 and to 908 million in 2007. Despite the relative slowdown during the two-year period 2008-2009 due to global financial instability, the long-term upward trend in global tourist arrivals continued in the following years and in 2010 global arrivals reached 940 million travelers. This upward trend has continued in recent years. In 2012, for the first time, tourism 
exceeded 1 billion in international arrivals, while it is estimated that in 2025 international tourist arrivals will have exceeded 1.80 billion (Karamanakou \& Karamountzou, 2014; WTTC, 2015; UNWTO, 2019). As evidenced, by the time course of this evolution, any deceleration or even reversal, due to adverse circumstances (as the recent COVID 19 pandemic), is temporary and does not seem to stop this positive long-term trend.

Tourism, as an economic activity, is characterized by a high demand elasticity. Moreover, as transport costs are significant for international transportation, demand is strongly influenced by this factor. Therefore, transport is a key element within the tourism industry. The strong demand in international, and even national transport means, infrastructure and services requires that people can be transported in an efficient, fast, and inexpensive manner. It requires heavy investments and complex planning (Rodrigue, 2020). Tourism is using all transportation modes. Travelers rely on existing passenger transport systems, from local transit systems to global air transportation. Litman (2020) identifies twelve transportation factors that effect a destination's accessibility. These are: 1 . The transportation modes quality of transportation options, with respect to safety, speed, and comfort, 2 . The network connectivity - density of link and path connections, or directness of travel between destinations, 3. The travel cost or the affordability, 4. The mobility - travel speed and distance, capacity, or the travel time, 5. The integration of the links and the modes within the transportation system, 6 . The transportation demand, 7 . The user information - availability of reliable information on mobility and the accessibility options, 8 . The mobility substitutes telecommunications and delivery service substitutes for physical travel, 9 . The transportation management, 10. The land use factors, 11 . The prioritization of travel activities, and 12 . The value of inaccessibility or isolation.

Consequently, it is widely accepted that transport is one of the main causes which affect tourism growth. Primarily, the improved infrastructure and facilities have incited tourism, but the expansion of tourism has encouraged the development of transport infrastructure and services, as well. Accessibility is the major function behind the basics of tourism transport (Papatheodorou et al, 2019). Tourists have a range of transportation modes that are often used in a sequence, to access popular destinations. The main transportation mode for international tourism is air transport, which normally entails travel over long distances. As already discussed, growth rates of international air traffic are closely correlated with growth rates of international tourism (Rodrigue, 2020).

Over time, successful air transport practices have developed. The aim of this paper is the presentation of the most successful practices in air transport sector and the implementation of such strategies in the context of road transport in tourism using Greece as a case study.

\section{TRENDS AND INTERMODALITY BETWEEN AIR TRANSPORTATION AND TOURIST COACH PASSENGER TRANSPORTATION}

Despite the problems that have emerged over time concerning air transportation (Williams, 2001; Graham, 2006; Klophaus, et al., 2012; Pearce, 2012; Lohmann \& Koo, 2013; Budd, et al., 2014; Papatheodorou\& Pappas, 2018; Pappas, 2018) highlighting e.g., the recent bankruptcies of Air Berlin, Primera Air and Germania, it may be argued that the sector of air 
transportation has significantly evolved in almost all places around the globe. The fact that major changes have taken place in such an important sector for the economy and tourism development (Alderighi, et al., 2012) must be recognized as a very positive sign, bearing in mind that only the most efficient stakeholders will be able to financially survive and continue to be competitive within the industry. As a result, any negative effects regarding the seize of operations of a variety of companies should be considered as market restructuring.

A crucial role, regarding the changes that have taken place in the air transportation industry, have been strongly influenced by the liberalization of air transportation in USA in 1978 and in Europe (Budd, et al., 2014), with gradual appliance between 1988 and 1997.This mainly legal content procedure significantly favored the rapid development of Low Cost carriers (LCCs). All these practices can play an important role in land transportation and especially in the sector of tourist coaches, which is of major significance in Greece.

\subsection{The Institutional Framework of Road Passenger - Tourist Coach Transportation in Greece}

At a national level, as well as according to the current legal framework, the road passenger transportation in Greece is distinguished between regular and irregular public road passenger transportation. Regular road passenger transportation is connected to the operation and exploitation of regular transportation in urban lines and long distance lines among cities within the country and is considered a public good. The term regular road passenger transportation refers to the passenger road transportation following certain lines with predetermined journeys and frequency, along which passenger can get on- and off- board at predetermined coach stops. This transportation duty has been exclusively assigned by the State to: a) KTEL companies - the Coach Common Collection funds operating one at each Prefecture as far as long distance lines among cities are concerned and b) Urban KTEL companies or municipality transportation companies, as far as urban lines within cities are concerned. The public regular urban and long distance lines are not a popular means of transportation for tourists to visit different cities, sightseeing or islands within Greece. According to the official second degree body of public lines operators (Pan-Hellenic Federation of Motorists for Intercity Transportation - P.F.M.I.T.) only $1-1.5 \%$ of annual turnover concerning long distance lines can be attributed to tourism transportation.

On the other hand, the irregular road passenger transportation involves operations of nontactical or last minute "closed doors" transportation of a predetermined group of people with their luggage connecting two places, having in no case the essence of regular transportation with certain coach stops, which is prohibited. This kind of transportation has been exclusively assigned to tourist coaches (public use vehicles) and contains the transportation of: a) group of people for the needs of organized conferences, exhibitions, seminars, athletic, cultural and social events, b) group of people in organized excursions inside or outside the country, c) group of people from/ to airports, sea ports, railways and border stations, d) group of employees from/ to their working place, e) group of people for sea swimming and f) group of students in organized excursions, as well as from/ to their schools. 
Setting a tourist coach in official operation presupposes the existence of:

a) either a travel agency with a Legal Operating Budge granted by the Greek National Tourism Organization, which belongs to the Ministry of Tourism as a supervising authority; or

b) a Tourism Road Transport Company (T.E.O.M.) with its own Legal Operating Budge granted by the Greek National Tourism Organization.

In both cases, co-responsible for the technical standards and the approval of the type of the tourist coach is the Passenger Transportation Directorate of the Ministry of Infrastructure and Transport.

According to the Greek State Law (393/1976, Article 1), the activity and operation of travel agencies is described as: "Travel agencies are permanently organized companies which undertake the transportation or overnight stay of individuals or group of people, within the borders or outside the Country. Their operations consist of: a) the scheduling and execution of excursions within or outside the country by an owned or rented for this reason transportation vehicle or by any means of sea, air or land transportation, b) the mediation for locating or renting accommodation, finding a place to eat, entertaining and renting other transportation means, c) the issuance of all kind of transportation tickets, d) the organization of conferences of all kinds, e) the receipt and shipment of luggage of domestic or foreign clients, f) the mediation for the issuance of new passports to clients and g) the offering of any other service directly or indirectly related to tourism such as the promotion of tourist companies, as well as the distribution of cultural events' tickets organized by the Greek National Tourism organization or by other bodies." Likewise, a Tourism Road Transport Company (T.E.O.M.) can be described as a tourism company owning or renting one or more tourist coaches, while at the same time it does not operate as a travel agency (Greek State Law 711/1977). According to the Greek Ministry of Tourism, in Greece there are: a) 5,384 Travel Agencies and annexes of them with Legal Operating Budge, 305 of which have an online only presence, without data concerning the ownership of tourist coaches, and b) 1,571 Tourism Road Transport Companies (T.E.O.M.), 616 of which own 616 tourist coaches in total.

Despite the liberalization of road passenger transportation, the distinction between a travel agency and a T.E.O.M. still remains in practice. However, the extended number of provided services by T.E.O.M. - without the intermediation of travel agencies - remains effective. The only exception between the two operational models is the transportation of passenger and students regarding organized excursions. For such organized excursions T.E.O.M can still lease their tourist coaches to travel agencies - without organizing the excursion - by engaging in a written contract, either for one or more transfers on demand and/or for longer-term cooperation.

According to the Greek State Law (4254/2014, $6^{\text {th }}$ subparagraph of first article, point 14 ) "removal of barriers in competition in tourism sector - tourism transportation" the market of tourist coach licenses became liberalized for all interested parties, old and new stakeholders, removing the entry barriers that until then existed. Any individual interested may now apply for a new license for a tourist coach under the condition that at the same time holds a License for Road Transportation and owns either a travel agency or a T.E.O.M. company. The only applicable restriction is the age of the vehicle which cannot exceed a five-year barrier. Instead, an individual may also buy an existing tourist coach license, through the free market, including the above mentioned conditions and no other restriction. 
The representative body of the road passenger transportation in Greece estimates that the number of tourist coaches in operation in Greece operating the regular lines and belonging to KTEL, to be around 4,000 vehicles when at the same time the vehicles owned by travel agencies and TEOMs to be more than 5,800. The fact that no updated record exists concerning the exact number of vehicles in road passenger transportation, with an obvious negative effect on statistical data and the ability to reach useful conclusions, has urged the state to issue an Electronic Budge for all tourist coaches. Responsible for the issuance of this Electronic Budge to owners is the General Pan-Hellenic Federation of Tourism Enterprises (GEPOET), a second degree body of travel agencies' and tourist coaches' owners in Greece.

As it can be discerned, despite the existing legislation and the continuous efforts of tourism entrepreneurs and their representative bodies, the liberalization of the road passenger transportation has not yet been achieved, even though since 2011 it has been recorded as a prerequisite reform for Greece to receive funding from the IMF and the European Union. As a result, KTEL, urban KTEL or municipal passenger transportation companies, which are regular line passenger transportation companies, may also own and operate a travel agency with tourist coaches for irregular transportation, while the opposite is still not allowed. No one apart from the above mentioned companies can operate the regular lines throughout the country. In this context, the liberalization of the regular urban and long-distance line passenger transportation, an activity in which tourist coaches meet all the necessary specifications to participate, remains a challenge of the forthcoming period. After multiple extensions, the current regime of regular line operation should have ended by 31/12/2019. However, it has not been completed yet, even though new, reformed legislation is available to be enforced which determines the exact guidelines, the announcement of international tender proposals for each regular line as well as other provisions. Therefore, the regular passenger transportation is currently performed with tacit extension of the previous regime, which is beyond legal provisions.

The above mentioned reformed legislation enacts the Transport Regulating Authority (R.A.E.M.), which will have a strategic role of setting an international tender for the whole network of regular long distance lines, according to local needs as well as in classifying the regular lines as subsidized, open to free-market competition, etc. Furthermore, according to the Greek State Law 4568/2018, passenger tourist transporters, including coaches, are allowed under certain conditions to engage in urban regular transportation in the areas managed by O.A.S.A S.A. and O.S.E.TH. S.A., which are in Athens and Thessaloniki respectively. This amounts to a legislative provision that is equivalent to a partial liberalization of urban regular passenger transportation with the market entry of private companies. In any case, the full liberalization of urban and long distance regular road passenger lines is not expected to be completed before the end of 2021 under normal conditions. However, it is expected to lead to a severe reduction in the cost of transportation for passengers and accompanied at the same time by services of significantly higher quality.

\subsection{Air Transport Best Practices applied in Land Transportation of Passengers}

Based on the above discussion, it can be argued that regular line passenger transportation companies such as KTEL, have the right to establish and operate tourist coach services 
through the establishment and operation of a travel agency; tourism companies - travel agencies do not have the right to operate regular passenger services and individual tourists between cities. Below is a list of trends in the field of land transportation focusing on tourist coaches where aviation practices can be fruitfully applied for the optimal performance of this sector also in the context of intermodality.

As mentioned before, the deregulation/liberalization of air transport in the USA and later in the EU, has led to the rapid growth of the sector and especially to the development of LCCs. These have a $36 \%$ market share of seats offered in Europe, which is expected to reach $50 \%$ by 2027 (Anna.aero, 2018). The rapid growth of air transport has led to intensified competition, which in turn has reduced air fares. Whilst in Greece the monopoly in the commercial exploitation of urban and long-distance coach connections is still valid, in countries such as the USA, the UK, Sweden and recently, Germany, full liberalization in this sector has been achieved (Knorr \& Lueg - Arndt, 2016). In the case of the UK, a market of particular interest, the liberalization and privatization of transport-related organizations has been a reality for several decades. By using the example of Gatwick Airport in London, and analyzing the airport's coach connections, it is evident that passengers are provided with a choice of five different regular coach lines, i.e., Metrobus, Easybus, Megabus, National Express and Oxford Bus, as well as a choice of custom itineraries, after customers' communication or request via Gatwick Flyer. According to GEPOET, the liberalization of intercity transport could reduce ticket prices in Greece by up to $25 \%$ on average.

The growth of LCCs, during the second period of aviation developments (early 1990s to mid and late 2000s) highlighted the innovation brought about by LCCs to the nature and characteristics of the passengers traveling with this type of airlines. The emerging and developing LCCs of the time, applied a simplified service model, similar to charter carriers, to passengers who did not belong to an organized group of travelers. This innovation can also be applied in the sector of tourism coaches, to increase revenues and expand their customer base by creating new routes. The implementation of this innovation will be a form of hybridization on land tourist transportation. Besides, the existing legislation allows the transfer of individual passengers by tourist coaches from / to airports and ports if the reservation has been made in advance to create a pre-formed group and the transfers do not have "regular line" characteristics. It is also allowed to sell individual passenger seats on road trips with tourist coaches inside and outside of the country's borders.

Using once again the example of Gatwick Airport, research findings show that coaches' routes operating from the airport concern either certain areas of London, e.g., Chelsea, or cities connected to London by road, such as Bristol, Birmingham, and Cardiff. Thus, any passenger travelling to these cities can board directly, without the need to connect through an intercity coach station or to another stop, i.e., a practice that would result in increased inconvenience and total travel time. In Greece there are two main hub airports with all-year round international air connectivity i.e., the airports of Athens and Thessaloniki. These airports have valid characteristics for the implementation of such policies, as both Athens and Thessaloniki are close to a multitude of cities connected by road with a transfer time of about 1-2 hours. Especially in the case of Thessaloniki, the transfer from the airport to both the railway station and mainly to the intercity coach station, is by bus and especially time consuming during the peak traffic hours of the day. The strategy of making even a small number of routes directly 
departing from the airport to some neighboring cities, could substantially reduce total travel time. A fortiori, it should be noted that many of the British cities connected to Gatwick Airport operate their own airports which are connected to several European cities; this is not the case in Greece, as only Athens and Thessaloniki airports offer such air services on an all year round basis (Papatheodorou and Koura, 2012).

The significant decline of tour operators, caused by the increase of individual travelers flying with LCCs as well as the development of e-bookings on the Web, are some of the trends which made tour operators decide and implement the removal or reduction of activities complicating their business model. Among the first interests to be divested where those in airlines, as their high operating costs and the intensification of competition were making vertically integrated tour operations financially challenging. Currently, there is a small number of tour operators that have their own airlines, also selling seat-only tickets on their own websites. Even those large tourist groups that did not decide to divest of their interests in airlines, took measures to significantly reduce costs. As an example of this strategy, TUI Group merged five out of its six airlines around the TUI brand, changing the initial names of the local tour operators and adding the name of the country in which the respective company is based, e.g., TUI Airlines Belgium, TUI Airlines Netherlands etc. Thomas Cook shortly before its bankruptcy in 2019 was considering selling its airline, while Apollo, the largest tour operator in the Nordic countries, has kept its Novair brand with just two aircraft, overwhelmingly carrying out its travel schedule through other companies such as SAS, Widerøe, etc.

Having the above in mind, tour operators can reduce the verticalization of their land transport activities by creating separate companies with tourist coaches as a unique activity. For example, a few years ago, TUI Hellas, a subsidiary of the German tour operator, divested of the ownership of its domestic tourist coach fleet, transferring it to a domestic tourist coach management company. Retaining only the part of transferring and accommodating of its customers, it is now leasing tourist coaches from third parties to transfer its passengers to / from the airports and ports of their destination. This strategy is also recommended for travel agents suffering from financial burdens because of privately owned coaches.

It is also important to note that airlines increase their ancillary revenues by providing a series of out/in-flight services. In this context, tourist coaches may introduce the following services: - issuance of e-ticket through their own websites as well as through online travel agencies;

- ticket pricing, depending on the booking period;

- baggage charge beyond a certain allowance, e.g., 20kg per passenger;

- Wi-Fi service provision at an extra charge and special charging sockets for mobile devices;

- joint promotion and combined ticket with other transport modes e.g., airlines and trains and discount offering on such joint fares;

- combined ticket offering of urban, intercity travel, nature touring routes via coach or among air travel and touring routes. According to the representatives of the four companies that operate hop-on / off coaches in Athens, most of their customers come from cruise ships calling at Piraeus port. Thus, an agreement between airlines and coaches on the offering of a combined ticket can result into a passenger increase, especially for those city destinations which offer many attractions. Moreover, the dependency of those cities on the cruise sector can be significantly reduced. 
Finally, market power concentration and streamlining of operations via the formation of airline alliances, has been used as a strategy followed by Full Service Network Carriers to react against the rising profile of the LCCs. A similar strategy can be adopted by tourist coaches, offering increased economies of scale, cost reduction and strengthening in relation to the competition. On the other hand, it is a strategy which requires an optimal planning and monitoring, as the existence of a heterogeneous fleet of vehicles, may cause increases in operational costs and result in planning errors.

\section{SUMMARY AND CONCLUSIONS}

Transportation remains a fundamental pillar of spatial and tourism development. The constant increase of global passengers led to a surge of demand of better and more efficient transportation. Closely monitoring the airline sector, road transportation developed and rapidly became a crucial stakeholder of the industry. In Greece, the road transportation industry is divided in two main sectors: the regular and irregular public road passenger transportations. Both sectors are widely affected by the Greek legal framework and due to that fact, their operations are constrained. This paper highlighted some important issues in the Greek legal framework and identified opportunities for the creation for a friendly business environment and the further development of the sector in Greece. At the same time, all stakeholders need to pursue a customer-oriented strategy focusing on individual passengers. The expansion of the existing network as well as the introduction of new companies is thoroughly needed. Finally, and based on the airline sector experience, the offer of bundled services for passengers, the introduction of ancillary revenue strategies and the formulation of allied groupings may prove of essence for the financial sustainability and prosperity of tourist coaches in Greece.

\section{ACKNOWLEDGEMENTS}

This research has been co-financed by the European Union and Greek national funds through the Operational Program Competitiveness, Entrepreneurship and Innovation, under the call RESEARCH — CREATE — INNOVATE (Project Code: T1EDK--03052).

\section{REFERENCES}

- Alderighi, M., Cento, A., Nijkamp, P. \& Rietveld, P., 2012. Competition in the European aviation market: the entry of low-cost airlines. Journal of Air Transport Geography, Issue 24, pp. $223-233$.

- Anna.aero, 2018. LCC capacity in Europe set for half a billion seats in 2018; nine nations already at $50 \%$ market share; European share forecast for $50 \%$ in 2027 . Available at: https://www.anna.aero/2018/07/18/lcc-capacity-in-europe-set-for-half-a-billion-seats-in2018/ [Accessed 5 March 2019].

- Benevolo, L., 1980: The history of the City, London: Scholar Press.

- Bithas, K. and Nijkamp, P., 1997, Critical factors for an effective and efficient multi-modal freight transport network in Europe, Innovation: The European Journal of Social Science Research, Vol. 10(3), pp. 243-258. 
- Budd, L., Graham, F., Humphreys, I. \& Ison, S., 2014. Grounded: Characterizing the market exit of European low cost airlines. Journal of Air Transport Management, Issue 34, pp. $78-85$.

- Christofakis, M., 2014, Transport Cost in Location Practice and Economic Geography: Traditional theories, some new dimensions and policy implications, Bulletin of Geography. Socioeconomic Series, Vol. 25, pp. 55-67.

- Doganis, R., 2019. Flying off Course: Airline Economics and Marketing, $5^{\text {th }}$ edition. London: Routledge.

- Fernández, X. L., Coto-Millán, P. \& Díaz-Medina, B., 2018. The impact of tourism on airport efficiency: The Spanish case. Utilities Policy, 7 September, Issue 55, pp. 520- 58.

- Graham, A., 2006. Have the major forces driving leisure traffic changed?. Journal of Air Transport Management, Issue 12, pp. 14 - 20.

- Homsombat, W., Lei, Z. \& Fu, X., 2014. Competitive effects of the airlines-within-airlines strategy - Pricing and route entry patterns. Transportation Research , E(63), pp. 1 - 16.

- Karamanakou, E., and Karamountzou, M., 2014 (in Greek), The evolution of the tourist traffic in Greece and the competition with the other countries, Higher Technological Institute of Piraeus, Department of Accounting, Piraeus.

- Klophaus, R., Conrady , R. \& Fichert, F., 2012. Low cost carriers going hybrid: Evidence from Europe. Journal of Air Transport Management, Issue 23, pp. 54 - 58.

- Knorr, A. \& Lueg - Arndt, A., 2016. Intercity bus deregulation in Germany - Intramodal and intermodal effects after two years. Research in Transportation Economic, 14 June, Issue 59, pp. 323 - 329.

- Labrianidis, L., 2001 (in Greek), Economic Geography: Theoretical elements and empirical examples, Athens: Patakis.

- Law 2446/1996 (Gov. Gaz. A 276/19.12.1996), "Amendment of Law 711/1977 (Gov. Gaz. A 284) about special tourist coaches and remaining provisions" (in Greek).

- Law 2963/2001 (Gov. Gaz. A 268/23.11.2001), "Organization and operation of public passenger transportation with coaches, technical audit and safety of land transportation and rest provisions" (in Greek).

- Law 393/1976, (Gov. Gaz. A 199/31.7.1976), "About establishment and operation of Travel Agencies" (in Greek).

- Law 3534/2007, (Gov. Gaz. A 40/23.2.2007), "Issuance of Authority for allocation of available usage time to Greek airports and rest provisions", article 17, paragraph 9 (in Greek).

- Law 4070/2012. (Gov. Gaz. A 82/10.04.2012), "Settings concerning Electronic communications, Transportation, Public Works and rest provisions" (in Greek).

- Law 4199/2013 (Gov. Gaz. A 216/11.10.2013), "Public long distance road passenger transportation, Transportation Regulation Authority and rest provisions" (in Greek).

- Law 4254/2014 (Gov. Gaz. A 85/07.04.2014), "Measures for the support and development of the Greek economy while in application of law 4046/2012 and rest provisions" (in Greek).

- Law 4568/2018, (Gov. Gaz. A 178/11.10.2018), "Issues of waterfront ports, urban road transportation and rest provisions", article no 54 (in Greek).

- Litman, T., A., 2020, Evaluating Accessibility for Transport Planning Measuring People's Ability to Reach Desired Goods and Activities, Victoria Transport Policy Institute, available at: https://www.vtpi.org/equity.pdf (accessed: 5/10/2020).

- Lohmann, G. \& Koo, T. T., 2013. The airline business model spectrum. Journal of Air Transport Management, Issue 31, pp. 7 - 9. 
- metaforespress.gr, 2017 (in Greek), The prospects for passenger and freight transport by land, sea and air, according to the International Transport Forum, available at:

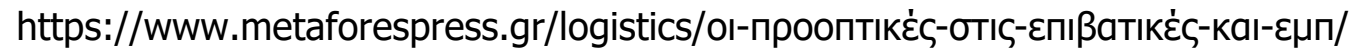

(accessed: 24/01/2019).

- Ministerial Decision 7073/17.05.2011, (Gov.Gaz. B 1266/ 16-6-2011), "Administration procedure for issuance of Special Operating Budge for Tourism Road Transport Companies (T.E.O.M.).

- Papatheodorou, A. and Koura, F. 2012. Customer Satisfaction from Public Service Obligation (PSO) Routes: Thessaloniki as a Case Study, Journal of Air Transport Studies, 3(2): 23-37.

- Papatheodorou, A., Vlassi, E., Gaki, D., Papadopoulou-Kelidou, L., Efthymiou, M., Pappas, D. and Paraschi, P. 2019. The Airline - Airport - Tourism Destination Authority Relationship: The Case of Greece. In Kozak N., Kozak M. (eds) Tourist Destination Management: Tourism, Hospitality \& Event Management. Berlin: Springer, 27-41.

- Pearce, B., 2012. The state of air transport markets and the airline industry after the great recession. Journal of Air Transport Management, pp. 3 - 9.

- Rodrigue, J-P., 2020, Tourism and Transport, The Geography of Transport Systems, available at: https://transportgeography.org/?page_id=9622 (accessed: 24/9/2020).

- Sven, M., 2018. A metric to assess the competitive position of airlines and airline groups in the intra-European air transport market. Research in Transportation Economics, Issue 72 , pp. $65-73$.

- United Nations World Tourism Organisation (UNWTO), 2019, World Tourism Barometer, Volume 17, Issue 1, January 2019, available at: http://cf.cdn.unwto.org/sites/all/files/pdf/unwto_barom19_01_january_excerpt.pdf (accessed: 23/2/2019).

- Williams, G., 2001. Will Europe's charter carriers be replaced by "no - frills" scheduled airlines? Journal of Air Transport Management, Issue 7, pp. 277 - 286.

- World Travel and Tourism Council (WTTC), 2015, Travel and Tourism Economic Impact 2015 World, available at: http://sete.gr/media/2614/150430-economic-impact-2015.pdf (accessed: 22/2/2019).

\section{AUTHORS' BIO}

Professor Dr Emmanouil Christofakis (corresponding author) is a Professor in Regional Development and Policy at the Department of Business Administration, University of the Aegean, Chios, Greece. Email: mchri@aegean.gr

Dr Theodoros Stavrinoudis is an Associate Professor in Management of Tourism Enterprises at the Department of Business Administration, University of the Aegean, Chios, Greece. Email: tsta@aegean.gr

Dr Spyridon Kapitsinas in an external associate of the Laboratory for Tourism Research and Studies, University of the Aegean, Chios, Greece. Email: skapits@hotmail.com 
Professor Dr Andreas Papatheodorou is a Professor in Industrial and Spatial Economics with Emphasis on Tourism at the Department of Business Administration, University of the Aegean, Chios, Greece. Email: a.papatheodorou@aegean.gr

Dimitrios Pappas is a PhD candidate at the Department of Business Administration, University of the Aegean, Chios, Greece. Email: dpappas@aegean.gr

Irini Vlassi is a PhD candidate at the Department of Business Administration, University of the Aegean, Chios, Greece. Email: ivlassi@aegean.gr

Evangelia Proiou is a member of the Laboratory for Tourism Research and Studies, University of the Aegean, Chios, Greece. Email: Iproiou@aegean.gr 